\title{
Dosage Effects of Aqueous Extract of Baobab Tree (Adansonia digitata Linn) Bark on Growth Performance, Blood Profile, Intestinal Morphology and Microflora of Cockerel Chickens
}

\author{
Opeoluwa ADEYOLANU ${ }^{1}$, Olajide SOGUNLE ${ }^{1 *}$, Olajide ADEYEMI ${ }^{1}$, John ABIONA ${ }^{2}$ \\ ${ }^{1}$ Department of Animal Production and Health, Federal University of Agriculture, Abeokuta, Ogun State, Nigeria. \\ ${ }^{2}$ Department of Animal Physiology, Federal University of Agriculture, Abeokuta, Ogun State, Nigeria. \\ Corresponding author: O. Sogunle: sogunleom@funaab.edu.ng
}

RESEARCH ARTICLE

\begin{abstract}
This experiment investigated the dosage effects of the aqueous extract of Baobab Tree Bark (AEBTB) on growth performance, blood profile and intestinal micro-flora of cockerel chickens for 16 weeks. A total of 200 Isa brown dayold cockerel chicks were used in groups of AEBTB $(0,300,325,350$ and $375 \mathrm{mg} /$ litre of water) for the experiment. Qualitative and quantitative $(\mathrm{mg} / 100 \mathrm{~g})$ phytochemical screening revealed that AEBTB contained flavonoid (36.33 $\mathrm{mg}$ ), cardiac glycoside (31.46 mg), saponin $(23.26 \mathrm{mg})$, alkaloid $(24.86 \mathrm{mg})$, tannin $(19.28 \mathrm{mg})$ and phenolic (17.06 $\mathrm{mg})$. The most common components in GS-MS was 9-Octadecenoic acid $\left(\mathrm{C}_{19} \mathrm{H}_{36} \mathrm{O}_{2} ; 296.0 \mathrm{~g} / \mathrm{mol}\right)$. At the chick phase, significantly $(\mathrm{p}<0.05)$ highest final weight $(416.50 \mathrm{~g} / \mathrm{bird})$ and weight gain of $47.69 \mathrm{~g} / \mathrm{bird} /$ day were recorded in birds on $375 \mathrm{mg} /$ litre when compared with the control. Alkaline phosphatase, RBC, Hb, PCV and MCHC were significantly $(\mathrm{p}<0.05)$ reduced by AEBTB in the birds when compared with the control and the lowest total bacterial count was in birds on $375 \mathrm{mg} / \mathrm{litre}$ of AEBTB. However, at the grower phase, birds on $300 \mathrm{mg} / \mathrm{litre}$ AEBTB had the best $(\mathrm{p}<0.05)$ feed conversion ratio. The study concluded that AEBTB at $300 \mathrm{mg} /$ litre improved health status and growth performance of meat-type chickens.
\end{abstract}

Keywords: Adansonia digitata bark extract; Performance; Phytochemicals; Gas Chromatography Mass Spectrometry; Intestinal microflora; Blood Profile.

Received: 27 November 2020 Accepted: 08 April 2021

Published: 14 May 2021

DOI:

10.15835/buasvmcn-vm:2020.0046

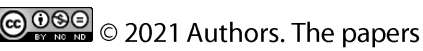
published in this journal are licensed under the Creative Commons Attribution-NonCommercialNoDerivatives 4.0 International License

\section{INTRODUCTION}

In the past, antibiotics have been used as feed additives to improve growth performance, egg production and to protect animals from pathogenic micro-organisms. The ban on the use of synthetic antibiotics as growth-promoting substance led to increase in research on organic acids and phytobiotics that are prebiotic and probiotic in nature (Patterson and Burkholder, 2003). These organic acids should be able to influence animal health and improve productivity. In spite of these promising medicinal values of Adansonia digitata bark, its full economic potentials have not been fully explored particularly in poultry production.

The Baobab fruit pulp shows interesting properties in the stimulation of the intestinal microflora growth. The hydrosoluble fraction of the fruit pulp has stimulating effects on the proliferation of bifido bacteria in in-vitro assays (Baobab Fruit Company, 2008). Soluble dietary fibres, as those contained in the pulp (about 25\%), are known to have prebiotics effects stimulating the growth and/or the metabolic activity of beneficial organisms (BFCS, 2008). Adansonia digitata root-bark and leaf methanol extracts have shown high antiviral activity against Herpes simplex, Sindbis and Polio (Anani et al., 2000), together with viricidal (direct inactivation of virus particles) and also intracellular antiviral activity, which could indicate the presence of multiple antiviral compounds, or a single compound with multiple actions (Hudson et al., 2000). 
Extracts of baobab roots eliminate the motility in Trypanosoma congolense within 60 minutes and drastically reduce motility in $T$. brucei and T. congolense which are the causative agent of sleeping sickness in humans and related diseases in animals (Atawodi et al., 2003).

The aqueous extract of the tree bark also has growth-stimulating effect and antibacterial properties. It is often given to infants to promote weight gain (Lockett and Grivetti, 2000) and had been found to be high in fat, calcium, copper, iron, and zinc (Lockett and Grivetti, 2000). In addition, it contains betulinic acid, alkaloid 'adansonin', (Odetokun, 1996; Sidibe and Williams, 2002). Stem and root barks of baobab contain bioactive constituents which are responsible for antimicrobial activity of the crude aqueous and ethanolic extracts. This explains the scientific basis for the use of crude stem and/or root bark extracts in traditional medicine (Masola et al., 2009).

The rural small resource-poor poultry farmers engage more in the rearing of cockerel chicken than broiler chicken because of low cost of production and lower susceptibility to disease. It is the male (under one year) of the hen from the egg-type chicken. Nowadays, the rearing of cockerel chicken is been given prominence unlike when it was been disposed of with as hatchery waste together with unhatched incubator eggs due to its hardiness and relatively high survival rate, though its production does not appear profitable due to its relatively long maturity period (Sogunle et al., 2013). Unlike in spent hens whose live weight decreases with increasing egg production and age, the live weight of a cockerel increases with age (Okosun, 1987). This study therefore investigated the potentials of aqueous extract of baobab tree bark on growth performance, blood profile, intestinal morphology and microflora of cockerel chickens.

\section{MATERIALS AND METHODS}

Fresh Boabab tree (Adansonia digitata L) bark was collected from the forest area of Abeokuta, Ogun State, Nigeria. The bark was chopped into smaller pieces and air-dried to reduce the moisture content to about $10 \%$. The dried Baobab tree bark was further ground into powdery form.

A total of $100 \mathrm{~g}$ powdered baobab bark sample was dissolved in $750 \mathrm{~mL}$ water for 48 hours in order to extract the polar compounds (Elgorashi and Van Staden, 2004) and then filtered using muslin cloth. The extract was then oven dried to reduce the moisture at $80^{\circ} \mathrm{C}$ inside hot air oven. The dried extract $(88 \mathrm{~g})$ was then ground into powdery form and stored in an air-tight plastic at room temperature for further use.

Experiment 1 was carried out at the Biochemistry Department Laboratory, and Animal Research Laboratory, Department of Pharmacology, College of Medicine, University of Lagos, Lagos. The Gas Chromatography Mass Spectrometry (GCMS) was carried out at Shimadzu Training Centre for Analytical Instruments (STC), Federal Institute of Industrial Research (FIIRO), Lagos State, Nigeria. Experiment II was carried out at the Poultry Unit of the Teaching and Research Farms, Federal University of Agriculture, Abeokuta, Ogun State, Nigeria. The site is located in the rain forest vegetation zone of South-Western Nigeria on altitude of $127 \mathrm{~m}$, latitude $7^{\circ} 13^{\prime} \mathrm{N}$ and longitude $3^{\circ} 26^{\prime} \mathrm{E}$ (Google Map, 2019).

Chemical tests were carried out on the aqueous extract of Baobab tree bark using standard procedures to identify the constituents as earlier described (Harborne, 1973; Sofowora, 1993; Madhu et al., 2016).

Preliminary qualitative phytochemical analysis was carried out to identify the secondary metabolites (saponins, alkaloids, phenolics content, tannins and flavonoids content) present in aqueous extract of baobab tree bark- AEBTB (Harborne, 1993; Trease and Evans, 1989; Madhu et al., 2016).

Gas Chromatography - Mass Spectometry (GC-MS) technique was used to identify the phyto-components present in AEBTB. The GC-MS used was a Schimadzu QP2010PLUS system. All the conditions used in GC-MS method were recorded in (Table 1). Identification of the peaks was based on computer matching of the mass spectra with the National Institute of Standards and Technology library and by direct comparison with published data (Van Den Dool and Kratz, 1963).

Table 1: GC-MS Method

\begin{tabular}{|c|c|}
\hline Model: & GCMS QP2010 SE Shimadzu \\
\hline \multicolumn{2}{|l|}{ GC Condition: } \\
\hline Column Oven temperature: & $60^{\circ} \mathrm{C}$ \\
\hline Injection port temperature: & $250^{\circ} \mathrm{C}$ \\
\hline Injection Mode: & Split $(3: 1)$ \\
\hline Column Oven temperature program: & $\begin{array}{l}60^{\circ} \mathrm{C} \text { by } 15^{\circ} \mathrm{C} / \mathrm{min} \text { to } 120^{\circ} \mathrm{C} \text { (hold time } 2 \mathrm{~min} \text { ) by } \\
15^{\circ} \mathrm{C} / \mathrm{min} \text { to } 300^{\circ} \mathrm{C} \text { (hold time } 4 \mathrm{~min} \text { ) }\end{array}$ \\
\hline Column Type: & Optima 5MS 30m*0.25mm*0.25um \\
\hline \multicolumn{2}{|l|}{ MS Condition: } \\
\hline Ion Source Temperature: & $200^{\circ} \mathrm{C}$ \\
\hline Interface Temperature: & $250^{\circ} \mathrm{C}$ \\
\hline Detector Voltage: & Relative to tuning result \\
\hline Acquisition Mode: & SCAN \\
\hline Scan range: & $45-700$ \\
\hline
\end{tabular}

The total phenolic content of AEBTB was estimated using Folin-Ciocalteau reagent by the method of Makkar et al. (2007). About $20 \mu \mathrm{g}$ of AEBTB was taken and made up to $1 \mathrm{~mL}$ with distilled water. Then $500 \mu \mathrm{L}$ of diluted Folins-phenol 
reagent (1:1 ratio with water) and $2.5 \mathrm{~mL}$ of sodium carbonate $\mathrm{Na}_{2} \mathrm{CO}_{3}(20 \%)$ was added. After incubation for 40 minutes in dark condition, the absorbance was measured at $750 \mathrm{~nm}$. A calibration curve of gallic acid was constructed and linearity obtained in the range of $10-50 \mu \mathrm{g} / \mathrm{mL}$. The total phenolic content of the AEBTB extracts was expressed as mg of gallic acid equivalent (mg GAE/100 g extract) by using the standard curve.

For flavonoids, a $5 \mathrm{~mL}$ sample of the extract dissolved in $3 \mathrm{~mL}$ of acidified ethanol was warmed slightly and then filtered. Few drops of Mayer's reagent and $1 \mathrm{~mL}$ of Dragendroff's reagent were added to $1 \mathrm{~mL}$ of the filtrate and turbidity was observed. The filtrate of AEBTB was used for the test as follows: $5 \mathrm{~mL}$ of dilute ammonia solution was added to AEBTB aqueous filtrate followed by the addition of concentrated $\mathrm{H}_{2} \mathrm{~S}_{4}$. A yellow colouration observed in the extract indicated the presence of flavonoids. The percentage of flavonoid was calculated as \% Flavonoid $=($ Weight of flavonoid*100)/Weight of sample

The method described by Madhu et al. (2016) was used for steroids determination. Acetic anhydride (2 mL) was added to $0.5 \mathrm{~g}$ AEBTB extract and $2 \mathrm{~mL} \mathrm{H}_{2} \mathrm{SO}_{4}$. The colour changed from violet to blue or green in some samples indicated the presence of steroids. The absorbance was at $780 \mathrm{~nm}$ against the reagent blank.

A sample of $0.5 \mathrm{~g}$ AEBTB was boiled gently in $20 \mathrm{~mL}$ of water for 1 hour in a test tube and then filtered using number $42(125 \mathrm{~mm})$ Whatman filter paper in a $100 \mathrm{~cm}^{3}$ of distilled volumetric flask. A few drops of $0.1 \%$ ferric chloride was added and observed for brownish green or a blue-black colouration which indicated the presence of tannin. Varying concentrations $\left(0.2-1.0 \mathrm{mg} / \mathrm{cm}^{3}\right)$ of the standard tannic acid solution were pipetted into five different test tubes to which Folin-Denis reagent $\left(5 \mathrm{~cm}^{3}\right)$ and saturated $\mathrm{Na}_{2} \mathrm{CO}_{3}\left(10 \mathrm{~cm}^{3}\right)$ solution were added and made up to the $100 \mathrm{~cm}^{3}$ mark with distilled water. The solution was left to stand for 30 minutes in a water bath at $25^{\circ} \mathrm{C}$. Optical density was ascertained at 700 $\mathrm{nm}$. Optical density (absorbance) versus tannic acid concentration was plotted. The following formula was used in the calculation:

Tannic acid $(\mathrm{mg} / 100 \mathrm{~g})=\left(\mathrm{C}^{*}\right.$ extract volume*100)/ (aliquot volume*weight of sample $)$

Where $\mathrm{C}$ is concentration of tannic acid read off the graph.

For saponin, AEBTB ( $2 \mathrm{~mL})$ was boiled in $20 \mathrm{~mL}$ of distilled water in a water bath and filtered. About $10 \mathrm{~mL}$ of the filtrate was mixed with $5 \mathrm{~mL}$ of distilled water and shaken vigorously for a stable persistent froth. The frothing was mixed with 3 drops of olive oil and shaken vigorously, then the formation of emulsion was observed. The saponin content was calculated as a percentage: $\%$ Saponins $=($ Weight of saponins $* 100) /$ weight of sample

$\operatorname{AEBTB}(0.5 \mathrm{~mL})$ was boiled with $2 \mathrm{~mL}$ of $1 \%$ aqueous hydrochloric acid for 10 minutes. Deposition of a red precipitate indicates the presence of phlobatannin.

AEBTB $(5 \mathrm{~mL})$ was mixed with $50 \mathrm{~mL}$ of $95 \%$ ethanol for 24 hours. The filtrate was extracted with petroleum ether $\left(60\right.$ to $\left.80^{\circ} \mathrm{C}\right)$ and concentrated to dryness. A reddish brown colouration of the interface was formed to show positive results for the presence of terpenoids.

For cardiac glycosides (Keller-Killani test), AEBTB $(5 \mathrm{~mL})$ was treated with $2 \mathrm{~mL}$ of glacial acetic acid containing one drop of ferric chloride solution and cooled. After cooling, 2-3 drops of ferric chloride were added. This was underlain with $1 \mathrm{~mL}$ of concentrated sulphuric acid. A reddish brown ring of the interface indicated a deoxysugar characteristic of cardenoloides. A violet ring appeared below the reddish brown ring, while in the acetic acid layer, a greenish ring formed just gradually throughout thin layer.

To $1 \mathrm{~mL}$ AEBTB, $20 \mathrm{~mL}$ of chloroform was added. This was heated in steam bath for 5 minutes. The extract was filtered while hot and allowed to cool. An equal volume of $10 \%$ ammonia solution was added to the filtrate. This was shaken and the upper aqueous layer was observed for bright pink colouration as indicative of the presence of Anthraquinones.

A total of two hundred Isa brown day-old cockerel chicks were used for the experiment. The birds were divided into five AEBTB treatment groups $(0 \mathrm{mg} / \mathrm{litre}, 300 \mathrm{mg} / \mathrm{litre}, 325 \mathrm{mg} / \mathrm{litre}, 350 \mathrm{mg} / \mathrm{litre}$ and $375 \mathrm{mg} / \mathrm{litre}$ three times a week, respectively) of forty birds each. Each treatment was further divided into four replicates comprising of 10 birds each in a Completely Randomized Design and were brooded on replicate basis from day-old for two weeks. All routine management practices were adhered to during the experiment which lasted 8 weeks. No vaccination and medication were given to the birds on AEBTB in the course of the experiment. Chicks mash (Table 2) and water were given ad libitum to the birds for the period of the experiment. Performance indices including body weight gain, feed intake, mortality and feed efficiency per replicate were recorded on a weekly basis.

Blood samples $(5 \mathrm{~mL})$ were obtained from brachial vein of 2 birds per replicate via the wing vein and emptied into 2 sets of well-labelled bottle; one containing Ethylene Diamine Tetra Acetate (EDTA) as an anti-coagulant while the other contained no anti-coagulant. The samples were analysed in the laboratory for haematological parameters and biochemical measurements.

Faecal swap samples were taken from 2 birds per replicate for microbial load count and Identification according to Cowan (1974). Biochemical identification tests were done to further characterize the bacteria isolates according to World Health Organization (WHO, 1983) manual for laboratory investigation of acute enteric infections. 
Table 2: Gross composition and proximate composition (\%) of chick's mash and growers mash for cockerel chickens

\begin{tabular}{lcc}
\hline \multicolumn{1}{c}{ Ingredients } & Chick mash & Growers mash \\
\hline Maize (Yellow maize) & 45.00 & 45.75 \\
Soyabean Meal & 11.70 & 8.00 \\
Wheat offals & 18.00 & 26.60 \\
Oyster shell & 3.00 & 6.00 \\
Bone meal & 2.00 & 2.00 \\
Groundnut cake & 9.60 & 11.00 \\
Palm kernel cake & 8.00 & 0.25 \\
Fish meal & 2.00 & 0.10 \\
Salt (NaCl) & 0.25 & 0.10 \\
Lysine & 0.10 & 0.25 \\
Methionine & 0.10 & 100.00 \\
Vitamin and Mineral Premix $*$ & 0.25 & 56.32 \\
\hline Total & 100.00 & 19.61 \\
\hline Determined Proximate Analysis: & & 5.19 \\
Carbohydrate (\%) & 33.20 & 8.45 \\
Protein (\%) & 21.10 & 3.71 \\
Crude fat $(\%)$ & 4.20 & 6.48 \\
Moisture (\%) & 5.72 & 352.43 \\
Ash (\%) & 12.10 & 9.37 \\
Crude Fibre (\%) & 254.50 & \\
ME (Kcal/100g) & & \\
\hline
\end{tabular}

Vit. A 12,500,000 iu; Vit. D3 2, 5000,000 iu; Vit E 40,000mg; Vit. K 32,000mg; Vit. B1 3,000 mg; Vit. B2 5,500 mg; Niacin 55,000 mg; Calcium Pantothenate 11, $5000 \mathrm{mg}$; Vit. B6 5,000 mg; Vit. $B_{12} 25 \mathrm{mg}$; Choline Chloride 500,000 mg; Folic acid 1,000 mg; Biotin 80 mg; Manganese 120,000 mg; Iron 100,000 mg; Zinc 80,000 mg; Copper 8,5000 mg; lodine 1,500 mg; Cobalt 300 mg; Selenium 120 mg; Anti-oxidant 120,000 mg. $\mathrm{ME}(\mathrm{kCal} / 100 \mathrm{~g})=$ Metabolizable energy

$\mathrm{ME}=4 *($ Carbohydrate + Protein $)+9 *$ Crude fat (Source: Merrill and Watt, 1973)

All data in phase 1 of the experiment were also taken in the second phase. However, a total of ninety-six cockerels were randomly selected from the AEBTB treatment groups in phase 1 while 24 birds were selected from the control group and used in the grower phase. The birds were subjected treatment groups of AEBTB (as in phase 1) but containing 8 birds of 3 replicates each. All management practices were adhered to while the birds were managed intensively for the period of the experiment. Growers mash (Table 2) was given to the bird's ad libitum. Fowl pox vaccine was administered to the birds before the beginning of the $2^{\text {nd }}$ phase of the experiment.

Data were subjected to One-way Analysis of Variance (ANOVA) in a Completely Randomized Design. Significantly $(\mathrm{P}<0.05)$ different means among variables were separated by Tukey test as contained in Minitab ${ }^{\circledR}$ version 17.1.0 (Minitab, 2013).

\section{RESULTS AND DISCUSSIONS}

Table 3 shows that saponin, alkaloids, phlobatanin, tannin, phenol, flavonoid and cardiac glycoside were phytochemical components of AEBTB while steroids, terpenoid and anthraquinone were absent in AEBTB.

Table 3: Phytochemical components of Baobab Tree Bark Extract

\begin{tabular}{lc}
\hline Compounds & Availability \\
\hline Saponin & + \\
Alkaloids & + \\
Phlobatanin & + \\
Tannin & + \\
Phenol & + \\
Steroids & - \\
Flavonoids & + \\
Cardiac glycoside & + \\
Terpenoid & - \\
Anthraquinone & - \\
\hline \multicolumn{1}{c}{$\quad$ Present; - Absent }
\end{tabular}

The quantification of phytochemical composition of AEBTB $(\mathrm{mg} / 100 \mathrm{~g})$ is presented in Table 4. AEBTB extract has higher concentration of flavonoid $(36.33 \mathrm{mg}$ ) and cardiac glycosides (31.46 mg). It also contained $23.26 \mathrm{mg}$ saponin, 24.86 $\mathrm{mg}$ alkaloid, $19.28 \mathrm{mg}$ tannin and $17.06 \mathrm{mg}$ phenol. 
Table 4: Quantitative estimation of the phytochemical constituents of Baobab Tree Bark Extract

\begin{tabular}{lc}
\hline \multicolumn{1}{c}{ Compounds } & Quantitative (mg/100g) \\
\hline Saponin & 23.26 \\
Alkaloids & 24.86 \\
Phlobatanin & ND \\
Tannin & 19.28 \\
Phenol & 17.06 \\
Steroids & - \\
Flavonoids & 36.33 \\
Cardiac glycoside & 31.45 \\
Terpenoid & - \\
Anthraquinone & - \\
\hline ND = Not determined & \\
- Absent &
\end{tabular}

The result of the gas chromatography-mass spectroscopy (GC-MS) analysis of the AEBTB identified the various compounds. These results are in line with the findings of Shukla et al. (2001) who reported that varieties of chemicals have been isolated and characterized from $A$. digitata which includes flavonoids, alkaloids, saponin and phlobatannin. The result however contradicted the reports by Abiona et al. (2015) that aqueous baobab tree (Adansonia digitata) leave extract contained steroids, terpenoids and anthraquinones. This could be due to the difference in geographical location and the parts of the baobab tree. Unlike the present study, Sugandha et al. (2014) reported reduced number of metabolites in aqueous AEBTB. These metabolites according to Narenda et al. (2012) and Vishnu et al. (2013) were reported to have many therapeutic properties.

In Table 5, the active compounds, area of peaks concentration percentage, retention time, molecular weight and formulae are presented. The most common components and highest peak in the ethyl acetate fraction as identified by GCMS was 9-Octadecenoic acid. The GC-MS spectrum gives the structure of the compound, molecular formula $\left(\mathrm{C}_{19} \mathrm{H}_{36} \mathrm{O}_{2}\right)$ and molecular weight of $296 \mathrm{~g}$. This phenolic hydroxyl group has a wide range of cellular activities (Geeta and Padma, 2013).

Table 5: Components in ethyl acetate fraction of Baobab Tree Bark Extract by GC-MS analysis

\begin{tabular}{|c|c|c|c|c|c|}
\hline Peak & $\begin{array}{c}\text { Retention } \\
\text { Time }\end{array}$ & $\begin{array}{c}\text { Area } \\
(\%)\end{array}$ & $\begin{array}{l}\text { Chemical } \\
\text { formula }\end{array}$ & $\begin{array}{c}\text { Molecular } \\
\text { weight }(\mathrm{g} / \mathrm{mol})\end{array}$ & Name of Compound \\
\hline 1 & 4.832 & 0.20 & $\mathrm{C}_{6} \mathrm{H}_{12} \mathrm{~S}$ & 116 & Cyclohexanethiol \\
\hline 2 & 5.784 & 0.15 & $\mathrm{C}_{8} \mathrm{H}_{12} \mathrm{O}_{4}$ & 172 & Diethyl maleate \\
\hline 3 & 7.618 & 0.21 & $\mathrm{C}_{7} \mathrm{H}_{12} \mathrm{O}_{2}$ & 128 & Butyl acrylate \\
\hline 4 & 8.553 & 0.07 & $\mathrm{C}_{16} \mathrm{H}_{28} \mathrm{O}_{2}$ & 252 & Hydnocarpic acid \\
\hline 5 & 9.145 & 0.10 & $\mathrm{C}_{9} \mathrm{H}_{16} \mathrm{O}_{4}$ & 188 & Azelaic acid \\
\hline 6 & 11.027 & 0.25 & $\mathrm{C}_{10} \mathrm{H}_{18} \mathrm{O}_{2}$ & 170 & 1-Octen-3-yl acetate \\
\hline 7 & 11.216 & 0.30 & $\mathrm{C}_{9} \mathrm{H}_{12} \mathrm{O}_{4}$ & 184 & 3-Methoxy-4-hydroxyphenylglycol \\
\hline 8 & 11.716 & 0.37 & $\mathrm{C}_{22} \mathrm{H}_{32} \mathrm{O}_{2}$ & 328 & Docosahexaenoic acid \\
\hline 9 & 12.066 & 0.21 & $\mathrm{C}_{18} \mathrm{H}_{34} \mathrm{O}_{2}$ & 282 & Oleic acid \\
\hline 10 & 12.529 & 0.21 & $\mathrm{C}_{13} \mathrm{H}_{26} \mathrm{O}$ & 198 & 1-Methylcyclododecanol \\
\hline 11 & 13.618 & 0.37 & $\mathrm{C}_{13} \mathrm{H}_{26} \mathrm{O}$ & 198 & Tridecan-2-one \\
\hline 12 & 14.107 & 0.88 & $\mathrm{C}_{18} \mathrm{H}_{32} \mathrm{O}_{2}$ & 280 & Linoleic acid \\
\hline 13 & 14.778 & 1.62 & $\mathrm{C}_{19} \mathrm{H}_{36} \mathrm{O}_{2}$ & 296 & Methyl oleate \\
\hline 14 & 15.303 & 1.10 & $\mathrm{C}_{18} \mathrm{H}_{35} \mathrm{NO}$ & 281 & 9-Octadecenamide \\
\hline 15 & 15.660 & 1.45 & $\mathrm{C}_{35} \mathrm{H}_{68} \mathrm{O}_{5}$ & 568 & 2-(Decanoyloxy)-3-hydroxypropyl docosanoate \\
\hline 16 & 15.938 & 4.18 & $\mathrm{C}_{15} \mathrm{H}_{30} \mathrm{O}_{3}$ & 258 & Methyl 3-hydroxytetradecanoate \\
\hline 17 & 16.349 & 4.19 & $\mathrm{C}_{18} \mathrm{H}_{35} \mathrm{NO}$ & 281 & 9-Octadecenamide \\
\hline 18 & 16.469 & 1.66 & $\mathrm{C}_{18} \mathrm{H}_{35} \mathrm{NO}$ & 281 & 9-Octadecenamide \\
\hline 19 & 16.668 & 6.49 & $\mathrm{C}_{18} \mathrm{H}_{33} \mathrm{ClO}$ & 300 & 13-Octadecenoic acid chloride \\
\hline 20 & 16.791 & 2.40 & $\mathrm{C}_{21} \mathrm{H}_{42} \mathrm{O}_{4}$ & 358 & 2,3-Dihydroxypropyl octadecanoate \\
\hline 21 & 16.995 & 16.88 & $\mathrm{C}_{18} \mathrm{H}_{32} \mathrm{O}_{2}$ & 280 & Octadecadienoic acid \\
\hline 22 & 17.057 & 6.13 & $\mathrm{C}_{15} \mathrm{H}_{30} \mathrm{O}_{3}$ & 258 & Methyl 3-hydroxytetradecanoate \\
\hline 23 & 17.125 & 9.36 & $\mathrm{C}_{19} \mathrm{H}_{38} \mathrm{O}_{4}$ & 330 & Propylene glycol monopalmitate \\
\hline 24 & 17.625 & 2.65 & $\mathrm{C}_{35} \mathrm{H}_{68} \mathrm{O}_{5}$ & 568 & Glyceryl 1,3-dipalmitate \\
\hline 25 & 17.855 & 4.22 & $\mathrm{C}_{15} \mathrm{H}_{34} \mathrm{OSi}$ & 258 & 1-Triethylsilyloxynonane \\
\hline 26 & 18.090 & 20.12 & $\mathrm{C}_{19} \mathrm{H}_{36} \mathrm{O}_{2}$ & 296 & 9-Octadecenoic acid \\
\hline 27 & 18.177 & 6.00 & $\mathrm{C}_{21} \mathrm{H}_{42} \mathrm{O}_{4}$ & 358 & Glyceryl monostearate \\
\hline 28 & 18.544 & 6.53 & $\mathrm{C}_{19} \mathrm{H}_{36} \mathrm{O}_{2}$ & 296 & 9-Octadecenoic acid \\
\hline 29 & 18.656 & 1.62 & $\mathrm{C}_{11} \mathrm{H}_{16} \mathrm{O}_{4}$ & 212 & 3,9-Diethylidene-2,4,8,10-tetraoxaspiro (5.5) undecane \\
\hline 30 & 20.800 & 0.12 & $\mathrm{C}_{35} \mathrm{H}_{52}$ & 472 & 2-Tert-butyl-10-nonyl-9-octylanthracene \\
\hline
\end{tabular}


These compounds show a wide spectrum of action which includes anti-tumour, antiviral, antibacterial and cardioprotective (Rice-Evans et al., 1996; Chen et al., 1998; Wang et al., 2008). Ultee et al. (2002) also reported that the presence of hydroxyl group plays an important role in antimicrobial activity. This attest to the fact that AEBTB may be used as an alternative to antibiotics.

Table 6 shows the effect of AEBTB on growth performance of cockered chicks. At the chicks' phase, the dosage of administration significantly $(\mathrm{P}<0.05)$ influenced final weight, daily weight gain and mortality of the cockerels. The weight gain ranged from $34.16 \mathrm{~g} / \mathrm{bird} /$ day to $47.69 \mathrm{~g} / \mathrm{bird} /$ day and it followed the same trend in the final weight gain. The mortality ratio was highest in the birds on $375 \mathrm{mg} / \mathrm{L}$ and lowest in birds on the control. However, at the growing phase, the dosage of administration significantly $(\mathrm{P}<0.05)$ affected the feed conversion ratio. The poorest feed conversion ratio feed conversion ratio was obtained in birds on $300 \mathrm{mg} / \mathrm{L}$ while the best was obtained in birds on $350 \mathrm{mg} / \mathrm{L}$ dosage administered. The improvement in the body weight gain may be as a result of the positive effect of the extract on the beneficial microorganism which helps in digestion. The result of this present study regarding weight gain and final weight coincides with the findings of Gunal (2006) and Owens et al. (2008) who reported that supplementation of organic acid in broiler chickens improved the body weight gain when compared with conventional antibiotics group. The higher mortality in AEBTB treatment compared to the control group resultedfrom disease (Salmonellosis) in the flock between weeks two and three of the experiment. In the growing phase, AEBTB improved feed conversion ratio when compared with the control treatment. The best feed conversion ratio was from birds on $350 \mathrm{mg} / \mathrm{L}$ of AEBTB. The improvement could result from improved feed utilization by AEBTB dosage administered on beneficial microorganism in the GIT. This observation supported the earlier findings of Hooge (2003) and Murshed and Abudabus (2015) who noted that supplementation of prebiotics improved feed conversion ratio.

Table 6: Effect of Aqueous extract of Baobab Tree Bark on growth performance of cockerel chicken

\begin{tabular}{|c|c|c|c|c|c|c|}
\hline $\begin{array}{c}\text { Dosage of } \\
\text { administration } \\
(\mathrm{mg} / \mathrm{l})\end{array}$ & $\begin{array}{c}\text { Initial } \\
\text { weight } \\
\text { (g) }\end{array}$ & $\begin{array}{c}\text { Final } \\
\text { weight (g/bird) }\end{array}$ & $\begin{array}{c}\text { Weight } \\
\text { gain } \\
\text { (g/bird/day) } \\
\end{array}$ & $\begin{array}{c}\text { Feed } \\
\text { intake } \\
\text { (g/bird/day) } \\
\end{array}$ & $\begin{array}{c}\text { Feed } \\
\text { conversion } \\
\text { ratio } \\
\end{array}$ & $\begin{array}{c}\text { Mortality } \\
(\%)\end{array}$ \\
\hline \multicolumn{7}{|l|}{ Chicks Phase } \\
\hline 0 & 35.00 & $396.80^{\mathrm{a}}$ & $45.22^{\mathrm{a}}$ & 224.10 & 5.00 & $15.00^{\mathrm{b}}$ \\
\hline 300 & 35.00 & $380.00^{\mathrm{ab}}$ & $43.13^{\mathrm{ab}}$ & 244.30 & 5.67 & $60.00^{\mathrm{a}}$ \\
\hline 325 & 35.00 & $416.50^{\mathrm{a}}$ & $47.69^{\mathrm{a}}$ & 249.40 & 5.27 & $20.00^{\mathrm{b}}$ \\
\hline 350 & 35.00 & $394.50^{\mathrm{a}}$ & $44.94^{\mathrm{a}}$ & 252.80 & 5.65 & $32.00^{\mathrm{ab}}$ \\
\hline 375 & 35.00 & $308.30^{\mathrm{b}}$ & $34.16^{\mathrm{b}}$ & 227.80 & 6.86 & $70.00^{\mathrm{a}}$ \\
\hline SEM & 0.91 & 17.10 & 2.17 & 13.30 & 0.57 & 8.92 \\
\hline P-value & 1.000 & 0.005 & 0.005 & 0.465 & 0.242 & 0.002 \\
\hline \multicolumn{7}{|l|}{ Grower Phase } \\
\hline 0 & 480.00 & 1147.50 & 11.92 & 70.89 & $5.98 \mathrm{a}$ & 8.34 \\
\hline 300 & 475.00 & 1155.00 & 12.14 & 74.91 & $6.14 a$ & 8.33 \\
\hline 325 & 475.00 & 1252.00 & 13.88 & 77.19 & $5.60 \mathrm{ab}$ & 16.67 \\
\hline 350 & 520.00 & 1305.00 & 14.01 & 68.88 & $4.91 b$ & 6.25 \\
\hline 375 & 502.50 & 1230.00 & 12.99 & 70.45 & $5.41 \mathrm{ab}$ & 12.50 \\
\hline SEM & 28.90 & 51.00 & 0.79 & 0.47 & 9.22 & 6.25 \\
\hline P-value & 0.750 & 0.199 & 0.262 & 0.713 & 0.009 & 0.775 \\
\hline
\end{tabular}

ab: Means on the same column by phase of growth with different superscripts differ significantly $(P<0.05)$

The effect of AEBTB on haematology, serum biochemistry and liver enzyme of cockerel chicks is presented in Table 7. The dosage of administration significantly $(\mathrm{P}<0.05)$ influenced red blood cell, haemoglobin concentration, packed cell volume and mean corpuscular haemoglobin concentration. Red blood cell and PCV followed the same trend with a numerically highest and lowest values from birds on $325 \mathrm{mg} / \mathrm{l}$ and $375 \mathrm{mg} / \mathrm{l}$ dosage of administration, respectively. Bird s on $300 \mathrm{mg} / \mathrm{l}$ had the highest haemoglobin concentration of 10.90 and the lowest value 5.10 was obtained in birds on 375 $\mathrm{mg} / \mathrm{l}$ dosage administered The effect of AEBTB on liver enzymes and serum biochemistry of cockerel chicks revealed that only alkaline phosphate was significantly $(\mathrm{P}<0.05)$ affected by dosage administered The values ranged from $138.00 \mu / \mathrm{mL}$ to $165.60 \mu / \mathrm{mL}$ with the highest value from birds in $300 \mathrm{mg} / \mathrm{l}$ and $350 \mathrm{mg} / \mathrm{litre}$ groups while the lowest was observed in birds administered $375 \mathrm{mg} / \mathrm{litre}$. 
Table 7: Effect of Baobab Tree Bark Extract on blood parameters and liver enzymes of cockerel chicks

\begin{tabular}{|c|c|c|c|c|c|c|c|}
\hline \multirow[b]{2}{*}{ Parameters } & \multicolumn{5}{|c|}{ Dosage of Administration (mg/l) } & \multirow[b]{2}{*}{ SEM } & \multirow[b]{2}{*}{ P-value } \\
\hline & $\mathbf{0}$ & 300 & 325 & 350 & 375 & & \\
\hline Red Blood Cell (x10²/l) & $2.20^{\mathrm{ab}}$ & $2.20^{\mathrm{ab}}$ & $2.25^{\mathrm{a}}$ & $1.17^{\mathrm{ab}}$ & $0.86^{\mathrm{b}}$ & 0.244 & 0.024 \\
\hline White Blood Cell $\left(\times 10^{3} / \mu 1\right)$ & 159.10 & 159.30 & 159.10 & 122.30 & 87.70 & 15.8 & 0.076 \\
\hline Haemoglobin $(\mathrm{g} / \mathrm{dl})$ & $10.30^{\mathrm{a}}$ & $10.90^{\mathrm{a}}$ & $10.05^{\mathrm{a}}$ & $7.00^{\mathrm{b}}$ & $5.10^{\mathrm{b}}$ & 0.478 & 0.001 \\
\hline Packed Cell Volume (\%) & $32.20^{\mathrm{a}}$ & $32.20^{\mathrm{a}}$ & $32.60^{\mathrm{a}}$ & $19.00^{\mathrm{b}}$ & $15.00^{\mathrm{b}}$ & 0.910 & 0.00 \\
\hline Mean Corpuscular Haemoglobin (Pg) & 11.30 & 13.50 & 10.40 & 9.90 & 9.70 & 0.738 & 0.068 \\
\hline $\begin{array}{l}\text { Mean Corpuscular Haemoglobin } \\
\text { Concentration }(\mathrm{g} / \mathrm{dl})\end{array}$ & $33.20^{\mathrm{ab}}$ & $39.60^{\mathrm{a}}$ & $27.30^{\mathrm{ab}}$ & $22.60^{\mathrm{b}}$ & $25.80^{\mathrm{b}}$ & 2.26 & 0.017 \\
\hline Mean Corpuscular Volume (fl) & 146.50 & 150.10 & 146.30 & 162.90 & 173.60 & 13.10 & 0.556 \\
\hline Lymphocyte (\%) & 2.20 & 2.10 & 3.15 & 9.60 & 4.20 & 3.76 & 0.6333 \\
\hline Total Protein $(\mathrm{g} / \mathrm{dL})$ & 52.50 & 54.80 & 53.50 & 52.50 & 51.40 & 1.60 & 0.657 \\
\hline Albumin $(\mathrm{g} / \mathrm{dL})$ & 48.60 & 47.40 & 46.10 & 44.50 & 43.70 & 3.26 & 0.814 \\
\hline Globulin $\left(\mathrm{x} 10^{3} / \mu \mathrm{l}\right)$ & 3.90 & 7.40 & 7.40 & 8.00 & 7.70 & 2.63 & 0.992 \\
\hline Blood Glucose (mg/dL) & 94.60 & 96.40 & 96.40 & 98.20 & 107.30 & 4.44 & 0.386 \\
\hline \multicolumn{8}{|l|}{ Liver Enzyme } \\
\hline Alkaline Phosphate (IU/L) & $163.60^{\mathrm{a}}$ & $165.60^{\mathrm{a}}$ & $142.50^{\mathrm{ab}}$ & $165.60^{\mathrm{a}}$ & $138.00^{\mathrm{b}}$ & 4.24 & 0.012 \\
\hline Aspartate Amino Transferase (IU/L) & 12.00 & 11.00 & 12.50 & 10.00 & 13.00 & 0.700 & 0.133 \\
\hline Alanine Amino Transferase (IU/L) & 14.00 & 14.50 & 16.00 & 13.20 & 16.00 & 1.23 & 0.481 \\
\hline
\end{tabular}

$\mathrm{ab}$ : Means on the same row with different superscripts differs significantly $(\mathrm{P}<0.05)$

Reports have shown that administration of medicinal compounds or drugs can alter the normal range of haematological parameters which could either be positive or negative (Adeneye, 2008). Either way, it could be used to explain blood relating function of chemical compound and plant extract (Yakubu et al., 2007) because it shows a physiological, nutritional and pathological state of an animal (Muhammed et al., 2000). The reduction in the RBC, haemoglobin, PCV and mean corpuscular concentration in the treatment indicated that the oxygen carrying capacity of the birds' blood would be reduced. This may be as a result of period of ill health caused by salmonella infection experienced by the birds in weeks 2 and 3 of the experiment. The result of this study supports the findings of Moss (1999) that reduction in the haemoglobin may be accompanied by fall in red blood cells and PCV. Muhammed et al. (2000) also opined that very low reading of RBC, haemoglobin can indicate anaemia. TP, ALT and AST were not affected by AEBTB extract when compared with the control at the chick phase. However, the ALP reduces as the dosage of AEBTB administered increases. This may be as a result of lower deamination done by liver when given AEBTB as compared to conventional antibiotics.

The result of the effect of AEBTB on microbial count and identification in cockerel chicks is presented in Table 8. It revealed that AEBTB significantly $(\mathrm{P}<0.05)$ affected the Total bacterial count. The highest was from $0 \mathrm{mg} / \mathrm{l}$ while numerically lowest values were observed from AEBTB dosed groups. The identification of bacteria shows that Klebsiella oxytoca and Pseudomonas aeruginosa were absent in $350 \mathrm{mg} / \mathrm{l}$ and $375 \mathrm{mg} / \mathrm{l} \mathrm{doses,} \mathrm{respectively.} \mathrm{Significantly} \mathrm{reduced}$ total bacterial count obtained in the dosed when compared the control may be as result of the phenolic compounds in the AEBTB to effect antibacterial properties which also increased as the dosage increased. The result of this present study is in agreement with the findings of Gunal et al. (2006) that organic acid significantly reduced the total bacterial count in broiler chickens. In addition, all the microorganism identified in the control were missing in two of out of AEBTB treatments. This could be a pointer that AEBTB had antibacterial effect on them especially during their ill health period. Unlike this present study, Mookiah et al. (2014) found reduced caeca E. Coli with increased probiotic usage in broiler chickens.

Table 8: Effect of Baobab Tree Bark Extract on bacterial count and identification of cockerel chicks

\begin{tabular}{|c|c|c|c|c|c|c|c|}
\hline \multicolumn{8}{|c|}{ Dosage of Administration (mg/l) } \\
\hline Parameter & $\mathbf{0}$ & 300 & 325 & 350 & 375 & SEM & P-value \\
\hline Total bacterial count (cfu/ML) & $2.80^{\mathrm{a}}$ & $1.90^{\mathrm{b}}$ & $1.30^{\mathrm{b}}$ & $2.00^{\mathrm{b}}$ & $1.30^{\mathrm{b}}$ & 0.127 & 0.003 \\
\hline Escherichia coli & + & + & + & + & + & & \\
\hline Staphylococcus saprophyticus & + & - & - & + & + & & \\
\hline Klebsiella oxytoca & + & + & + & - & - & & \\
\hline Pseudomonas fluoresce & + & - & - & + & + & & \\
\hline Pseudomonas aeruginosa & + & + & + & - & - & & \\
\hline Citrobacter species & - & - & + & - & + & & \\
\hline Bacillus subtilis & + & - & - & + & + & & \\
\hline
\end{tabular}

(+) Positive; (-) Negative 
The effect of AEBTB on blood parameters and liver enzymes of growing cockerels is presented in Table 9.

Table 9: Effect of Baobab Tree Bark Extract on blood parameters and liver enzymes of growing cockerel chickens

\begin{tabular}{|c|c|c|c|c|c|c|c|}
\hline \multirow{2}{*}{ Parameters } & \multicolumn{5}{|c|}{ Dosage of Administration (mg/l) } & \multirow[b]{2}{*}{ SEM } & \multirow[b]{2}{*}{ P-value } \\
\hline & $\mathbf{0}$ & 300 & 325 & 350 & 375 & & \\
\hline Red Blood Cell (x10 12/l) & 1.57 & 0.97 & 1.42 & 1.27 & 1.33 & 0.234 & 0.563 \\
\hline White Blood Cell $\left(\mathrm{x} 10^{3} / \mu \mathrm{l}\right)$ & 134.70 & 78.90 & 122.00 & 118.40 & 118.20 & 22.00 & 0.524 \\
\hline Haemoglobin $(\mathrm{g} / \mathrm{dl})$ & 10.00 & 5.80 & 8.60 & 8.10 & 9.45 & 1.09 & 0.204 \\
\hline Packed Cell Volume (\%) & 24.30 & 14.85 & 23.25 & 20.65 & 21.40 & 4.09 & 0.570 \\
\hline Mean Corpuscular Haemoglobin $(\mathrm{Pg})$ & 63.45 & 59.35 & 60.95 & 65.05 & 63.70 & 3.08 & 0.704 \\
\hline \multicolumn{8}{|l|}{ Mean Corpuscular Haemoglobin } \\
\hline Concentration $(\mathrm{g} / \mathrm{dl})$ & 41.10 & 38.95 & 37.15 & 40.15 & 39.90 & 1.96 & 0.691 \\
\hline Mean Corpuscular Volume (fl) & 154.45 & 152.55 & 164.20 & 162.55 & 160.22 & 2.30 & 0.056 \\
\hline Lymphocyte $(\%)$ & 1.85 & 0.55 & 1.40 & 3.50 & 1.10 & 174 & 0.791 \\
\hline Total Protein $(\mathrm{g} / \mathrm{dl})$ & 59.60 & 60.40 & 63.60 & 62.30 & 63.35 & 2.50 & 0.734 \\
\hline Albumin $\left(x 10^{3} / \mu \mathrm{l}\right)$ & 42.10 & 41.53 & 42.10 & 42.35 & 41.25 & 0.641 & 0.111 \\
\hline Blood Glucose (mg/dL) & 74.25 & 87.70 & 108.55 & 89.25 & 108.55 & 8.14 & 0.111 \\
\hline Globulin $\left(\times 10^{3} / \mu 1\right)$ & 17.50 & 18.85 & 21.50 & 19.95 & 22.10 & 2.89 & 0.786 \\
\hline \multicolumn{8}{|l|}{ Liver Enzyme } \\
\hline Alkaline Phosphate (IU/L) & 84.00 & 92.40 & 75.60 & 84.00 & 120.00 & 11.90 & 0.220 \\
\hline Aspartate Amino Transferase (IU/L) & 45.05 & 46.15 & 45.05 & 49.10 & 50.20 & 2.65 & 0.565 \\
\hline Alanine Amino Transferase (IU/L) & 53.05 & 48.65 & 53.05 & 48.65 & 57.50 & 6.57 & 0.856 \\
\hline
\end{tabular}

The dosage of administration had no significant $(\mathrm{P}>0.05)$ effect on all the parameters measured. None of the parameters considered on liver enzymes was significantly $(\mathrm{P}>0.05)$ affected by dosage administered. The present finding on the effect of AEBTB on haematology of growing cockerels is in accordance with earlier findings of Sheikh et al. (2010) that organic acid supplementation had no effect on the blood metabolites of the broiler chickens. However, the haematological values obtained in this study falls within the normal range for chicken reported by Mitruka and Rawnsley (1997). The liver enzymes concentration of growing cockerels among the treatments shows no significant variation when compared with control. This is in agreement with the findings of Abdel Fattah et al. (2008) that liver functions as measured by AST, ALT and TP were not affected by acetic and lactic acid. Birds on $375 \mathrm{mg} / \mathrm{L}$ had the numerically lowest Total bacterial count when compared with the control. This may be as a result of the antibacterial effect of the metabolites present in AEBTB at higher dosage. This result negates the findings of Gunal et al. (2006) that organic acid or mixture decrease the total bacteria and gram negative bacteria count. However, B. subtilus was absent in ileum at $375 \mathrm{mg} / \mathrm{L}$ dosage. This may be as a result of antibacterial properties of AEBTB.

The effect of dosage of AEBTB on gut microbial count and identification on growing cockerel chicken is shown in Table 10. It shows that the dosage of AEBTB did not significantly $(\mathrm{P}>0.05)$ affect the gut microbial count of the birds up to $375 \mathrm{mg} / \mathrm{L}$.

Table 10: Effect of Baobab Tree Bark Extract on bacterial count and identification of growing cockerel chickens

\begin{tabular}{|c|c|c|c|c|c|c|c|}
\hline \multirow[b]{2}{*}{ Parameter } & \multicolumn{4}{|c|}{ Dosage of Administration(mg/L) } & \multirow[b]{2}{*}{375} & \multirow[b]{2}{*}{ SEM } & \multirow[b]{2}{*}{ P-value } \\
\hline & $\mathbf{0}$ & 300 & 325 & 350 & & & \\
\hline Total bacterial count (unit) & 2.05 & 1.75 & 1.80 & 1.90 & 1.35 & 0.417 & 0.807 \\
\hline Escherichia coli & ++ & ++ & + & ++ & ++ & & \\
\hline Klebsiella oxytoca & + & ++ & ++ & + & + & & \\
\hline Citrobacter freundii & + & + & + & + & ++ & & \\
\hline Pseudomonas aeruginosa & + & + & ++ & + & ++ & & \\
\hline Pseudomonas fluoresces & + & + & ++ & + & ++ & & \\
\hline Bacillus subtilis & + & ++ & ++ & ++ & + & & \\
\hline Bacillus mycoides & + & + & + & + & -- & & \\
\hline Proteus mirabilis & ++ & + & + & + & + & & \\
\hline Staphylococcus Saprophyticus & ++ & ++ & ++ & + & + & & \\
\hline $\begin{array}{l}\text { (++) Highly positive } \\
(+) \quad \text { Moderately positive } \\
(--) \quad \text { Negative }\end{array}$ & & & & & & & \\
\hline
\end{tabular}

\section{CONCLUSION}

The result of the analysis revealed that AEBTB contained secondary metabolites and phenolic compounds which could make it appropriate as alternative to synthetic antibiotics.

AEBTB significantly reduced the total bacterial count in the ileum of cockerel chickens.

AEBTB can be used in cockerel chicken production from $300 \mathrm{mg} / \mathrm{L}$ and above without any deleterious effect. 


\section{Acknowledgments}

This research did not receive any specific grant from funding agencies in the public, commercial, or not-for-profit sectors.

\section{Conflict of Interest}

The authors hereby assert that there is absolutely no conflict of interest with any individual or organization regarding the materials used and discussed in the manuscript.

\section{REFERENCES}

1. Abdel-Fattah SA., El-Sanhoury MH, El-Mednay NM and Abdel-Azeem F. Thyroid activity, some blood constituents, organs morphology and performance of broiler chicks fed supplemental organic acids. International Journal Poultry Science, 2008; 7(3):215-222.

2. Abiona DL, Adedapo Z, Suleiman MK. Proximate analysis, phytochemical screening and antimicrobial Activity of Baobab (Adansonia digitata) leaves. Journal of Applied Chemistry (IOSR-JAC), 2015; 5: 60-65.

3. Adeneye AA. Haematopoetic effect of methanol seed extract of Citrus paradisi Macfad (grape fruit) in Wistar rats. Biomed Resources; 2008; 19:23-26.

4. Anani K, Hudson JB, de Souzal C, Akpagana K, Tower GHN, Amason JT, Gbeassor M. Investigation of medicinal plants of Togo for antiviral and antimicrobial activities. Pharmaceutical Biology, 2000; 38: 40-45.

5. Atawodi SE, Bulus T, Ibrahim S, Ameh DA, Nok AJ, Mamman M, Galadima M. In vitro trypanocidal effect of methanolic extract of some Nigerian savannah plants. African Journal of Biotechnology, 2003; 2: 317-321.

6. Baobab Fruit Company, Senegal (BFCS). DATA SHEETS. Sarl: Quartier 10eme, EX Riaom No 132, Pg 826, Thies, Senegal, 2008.

7. Chen ZP, Schell JB, Ho CT and Chen KY. Green tea (epigallocatechin gallate) show a pronounced growth inhibitory effect on cancerous cells but not on their normal counterparts. Cancer Letter. 1998; 1129:173-179.

8. Cowan ST. Cowan and Steel's Manual for the Identification of Medical Bacteria. $2^{\text {nd }}$ Edition, Cambridge University Press, Cambridge, 67-83, 1974.

9. Elgorashi EE, Van Staden J. Pharmacological screening of six Amaryllidaceae species. Journal of Ethnopharmacology, 2004; 90:27-32.

10. Geeta S, Padma K. Extraction, gas chromatography-mass spectrometry analysis and screening of fruits of Terminalia chebula Retz. for its antimicrobial potential. Pharmacognosy Resources, 2013; 5(3): 162-168.

11. Google Map. Federal University of Agriculture. 2019; Retrieved from https://earth.google.com/web/@ 7.22330744,3.44033719,137.84884575a,1046.69760578d,35y,100.57030218h,44.999 99706t,-0r/data=Cm4abBJmCiUweDEwM. Accessed October 2019.

12. Gunal M, Yayli G, Kaya O, Karahan N, Sulak O. The effects of antibiotic growth promoter, probiotic or organic acid supplementation on performance, intestinal microflora and tissue of broiler. International Journal for Poultry Science, 2006; 5: 149-155.

13. Harborne JB. Phytochemical methods - a guide to modern techniques of plant analysis. $2^{\text {nd }}$ edition. London: Chapman and Hall; 4-16.07010077152. 1973.

14. Hooge DM. Broiler chicken performance may improve with MOS. Feedstuffs. 2003; 6:11-13.

15. Hudson JB, Anani K, Lee MX, de Souzal C, Amason JT, Gbeassor M. Further investigation of the antiviral activities of medicinal plants of Togo. Pharmaceutical Biology, 2000; 38: 40-45.

16. Lockett CT, Grivetti LE. Food-related behaviors during drought: a study of rural Fulani northeast Nigeria. International Journal of Food Sciences and Nutrition, 2000; 51: 91-107.

17. Madhu M, Sailaja TN, Satyadev VSS and Satyanarayana MV. Quantitative phytochemical analysis of selected medical plant species by using various organic solvents. Journal of Pharmacognosy and Phytochemistry, 2016; 5(2): 25-29.

18. Makkar HP, Siddhuraju P, Becker K. Methods in Molecular Biology: Plant Secondary Metabolites. Totowa: Human Press. 2007; 93-100.

19. Masola SN, Mosha RD, Wambura PN. Assessment of antimicrobial activity of crude extracts of stem and root barks from Adansonia digitata (Bombacaceae) (African baobab). African Journal of Biotechnology 2009; 8 (19);. 5076-5083.

20. Merrill AL, Watt BK. Energy Value of Foods. Basics and Derivation. US Department of Agricultural Handbook. Pp 74. 1973.

21. Minitab 17 Statistical Software. Stable release 17.1.0 (Computer software). State College, PA: Minitab, Inc. 2013 Available from: www.minitab.com 
22. Mitruka BM, Rawnsley HM. Clinical Biochemical and Hematological References values in normal Experimental Animals. Masson Publishing USA., Inc. 1977. Pp. 278.

23. Mookiah S, Sieo CC, Ramasamy K, Abdullah N, Ho YW. Effects of dietary prebiotics, probiotic and synbiotics on performance, caecal bacterial populations and caecal fermentation concentrations of broiler chickens. Journal of the Science and Food Agriculture, 2014; 94 (2):341-348.

24. Moss PP. Blood Banking: Concepts and Applications. Philadelphia, PA: Saunders; 1999. Pp 12-34.

25. Muhammed NO, Adeyinka AO, Peters OM. Nutritional evaluation of Fungi-treated Cocoa Bean Shell. Nigerian Journal of Pure and Applied Science, 2000; 5:1059-1064.

26. Murshed MAI, Abudabos AMI. Effects of the Dietary Inclusion of a Probiotic, a Prebiotic or their Combinations on the Growth Performance of Broiler Chickens Nutrition. Brazilian Journal of Poultry Science 2015; vol.17 no.spe. Poultry feeding additives. Available from: http://www.scielo.br/scielo.php?script=sci_arttext\&pid=S1516$635 X 2015001000099 \& \operatorname{lng}=e n \&$ tlng=en

27. Okosun SE. Studies on calorie and protein requirements of cockerels. Ph.D. thesis, University of Ibadan, Ibadan, Nigeria. 1987; Pp 21-35.

28. Owens B, Tucker L, Collins MA, Mccracken KJ. Effects of different feed additives alone or in combination on broiler performance, gut microflora and ileal histology. British Poultry Science, 2008; 49:202-12.

29. Patterson JA, Burkholder KM. Application of prebiotics and probiotics in poultry production. Poultry Science, 2003; 82 (4): 627-31.

30. Rice-Evans CA, Miller NJ, Paganga G. Structure antioxidant activity relationship of flavonoids and phenolic acid. Free Radicals Biology Med. 1996; 20:933-56.

31. Sheikh A, Tufail B, Gulam AB, Masood SM, Manzoor R. Effect of dietary supplementation of organic acids on performance, intestinal histo-morphology, and serum biochemistry of broiler chicken. Veterinary Medicine International. 2010; doi: 10.4061/2010/479485

32. Shukla YN, Dubey S, Jain SP, Kumar S. Chemistry, biology and uses of Adansonia digitata - review. Journal of Medical and Aromatic Plant Science. 2001; 23: 429 - 434.

33. Sofowora A. Medicinal Plants and Traditional Medicine in Africa. Spectrum Books Ltd., Ibadan, 1993. $191-289$.

34. Sogunle OM, Olaniyi OA, Egbeyale LT, Akinola OS, Shittu TA, Abiola SS et al. Free range and deep litter production systems: Effect on performance, carcass yield and meat composition of cockerel chickens. Tropical Animal Health and Production, 2013; 45 (1) 281 -288.

35. Sugandha S, Ranjeeta C, Shashi R, Varsha P. Preliminary phytochemical evaluation of in vivo and in vitro plant parts of Adansonia digitata L.: An endangered medical tree. Universal Journal of Pharmacy, 2014; 3 (3): 34-40.

36. Trease GE, Evans WC. Pharmacognosy. $11^{\text {th }}$ Edition, Bailliere Tindall, London, 1989. 45-50.

37. Ultee A, Bennik MH, Moezelaar R. The phenolic hydroxyl group of carvacrol is essential for action against the foodborne pathogen Bacillus cereus. Applied Environmental Microbiology. 2002; 68:1561-1568.

38. Van Den Dool H, Kratz PD. A Generalization of the Retention Index System including Linear Temperature Programmed Gas - Liquid Partition Chromatography. Journal of Chromatography, 1963; 11, 463-471.

39. Vishnu R, Nisha R, Jamuna S, Paulsamy S. Quantification of total phenolics and flavonoids and evaluation of in vitro antioxidant properties of methanolic leaf extract of Tarenna asiatica - an endemic medicinal plant species of Maruthamali hills, Western Ghats, Tamil Nadu. Journal of Resource Plant Science. 2013; 2(2):196-204.

40. Wang ML, Suo X, Gu JH, Zhang WW, Fang Q, Wang X. Influence of grape seed proanthocyanidin extract in broiler chickens: Effect on chicken coccidiosis and antioxidant status. Poultry Science, 2008; 87:2273-2280.

41. World Health Organisation (WHO). Manual for Laboratory Investigations of Acute Enteric Infections. World Health Organization. Diarrhoeal Diseases Control Programme. 1983; Pp. 95.

42. Yakubu MT, Akanji MA, Oladiji AT. Haematological evaluation in male albino rats following chronic administration of aqueous extract of Fadogia agrestis stem. Pharmacology Management. 2007; 3:34-38. 